Article

\title{
Brexit under Scrutiny in EU Member States: What Role for National Parliaments in Austria and Germany?
}

\author{
Katharina Luise Meissner \\ Centre for European Integration Research, Department of Political Science, University of Vienna, 1030 Vienna, Austria; \\ E-Mail: katharina.meissner@univie.ac.at
}

Submitted: 1 February 2019 | Accepted: 27 May 2019 | Published: 27 September 2019

\begin{abstract}
Among national parliaments (NPs) in the EU, the Austrian Nationalrat and the German Bundestag stand out as strong legislatures in EU affairs. Both parliaments have used their rights to great extent in recent EU negotiations on international agreements such as the one with Canada on a Comprehensive Economic and Trade Agreement. Yet, in the negotiations with the UK their involvement varies. Why is this so? Scholarly work on Brexit so far focused on the European Parliament or the UK parliament, while attention to NPs in the EU27 is scarce. This article fills this void in research by tracing the Austrian and German parliaments' activities in the Brexit negotiations. Despite similar institutional strength I find that the German Bundestag is more extensively involved, particularly on an informal level, compared to the Austrian Nationalrat. The reason for this is Brexit's varying saliency in these two countries given their different levels of exposure to the UK's withdrawal. As saliency of a policy issue is considered a major explanatory factor for why NPs engage in EU affairs, the results of this article confirm this expectation within the realm of EU international negotiations.
\end{abstract}

\section{Keywords}

Brexit; European Union; international negotiations; national parliaments; saliency; United Kingdom

Issue

This article is part of the issue "Out of the Shadows, Into the Limelight: Parliaments and Politicisation", edited by Christine Neuhold (Maastricht University, The Netherlands) and Guri Rosén (University of Oslo, Norway).

(C) 2019 by the author; licensee Cogitatio (Lisbon, Portugal). This article is licensed under a Creative Commons Attribution 4.0 International License (CC BY).

\section{Introduction}

Negotiations on the withdrawal of the UK from the EU have been under way since 2017. The European Parliament (EP), according to Article 50 of the Treaty on $\mathrm{EU}$, will have to ratify an eventual agreement on the UK's withdrawal (Closa, 2019). Article 50 does not give any formal role to national parliaments (NPs) in the context of the withdrawal agreement. However, if an eventual agreement on future UK-EU relations becomes a mixed one, NPs will need to ratify it. It is therefore vital to understand NPs' roles and positions in the current withdrawal negotiations. Yet, little attention has been paid to parliaments in EU member states other than in the UK (except for Christiansen \& Fromage, 2019).

Given the sequence of Article 50 negotiations and (likely) subsequent talks on a future UK-EU mixed agree- ment, we may look at NPs in Brexit affairs against the background of their engagement in EU negotiations of international agreements. In these negotiations, NPs recently claimed a right to ratification as was the case in the EU-Canada Comprehensive and Economic Trade Agreement (CETA): Indeed, the European Court of Justice (ECJ) clarified that international agreements targeting indirect investments require consent by NPs (ECJ, 2017). This is part of a larger trend whereby NPs actively scrutinize EU affairs due to their upgraded role since the Lisbon Treaty (Cooper, 2012). Through mechanisms such as the Barroso initiative, inter-parliamentary cooperation, and scrutiny of national governments NPs have become increasingly assertive of their roles in the negotiation of EU international agreements (Jančić, 2017; RoedererRynning \& Kallestrup, 2017). While NPs obviously have no right to ratification on the Article 50 agreement, they 
can make use of the aforementioned instruments in the withdrawal negotiations.

Recent research shows, however, that there is considerable variation in parliamentary activities on EU affairs between NPs (Auel \& Christiansen, 2015; Winzen, 2012). This seems to apply to their engagement in EU international negotiations, too (Jančić, 2017; RoedererRynning \& Kallestrup, 2017). Regarding trade talks, parliaments in Austria and Germany vis-à-vis other NPs in the EU recently stood out as intensive scrutinizers of transatlantic agreements such as CETA. Yet, in the current Brexit talks on the UK's withdrawal from the EU, the German Bundestag is much more extensively involved than the Austrian Nationalrat as this article will show. Why is this so?

Relying on theorization of saliency as a trigger for parliaments' activities on EU affairs (Auel \& Christiansen, 2015), I argue that varying vulnerability of Austria and Germany to Brexit explains the differing levels of engagement in these negotiations. Even though both parliaments are considered strong legislatures with extensive information and participation rights in EU affairs (see Section 2; Pollak \& Slominski, 2003), I find that the German Bundestag is more involved in the Brexit negotiations than the Austrian Nationalrat. This is due to Germany's exposure to the UK's withdrawal from the EU while Brexit's impact on Austria is of smaller magnitude.

In what follows, the article sets up the puzzle of two strong NPs with varying involvement in the Brexit negotiations. Second, I put forward alternative explanations to NPs' activities in these negotiations, which rest on Euroscepticism and saliency of Brexit. Thereafter, I conceptualize NPs' involvement in Brexit affairs by covering formal as well as informal measures. Based on this conceptualization, the empirical section traces the Austrian Nationalrat and the German Bundestag in the Article 50 negotiations. In doing so, I argue that the reason for the Bundestag's more intensive involvement is Germany's vulnerability to Brexit compared to little expected impact in the case of Austria. The conclusion summarizes the results and reflects on their implications for continued negotiations.

\section{The Puzzle: Similar Strength, Different Involvement}

Research on NPs in EU affairs identifies institutional strength as an explanatory factor for NPs' scrutiny activities (Auel \& Höing, 2015). This is because it is costly in terms of time and resources for members of parliament (MPs) to collect information on EU affairs (De Ruiter, 2013, p. 1198). Therefore, parliaments need the formal powers and capacity in order to perform these costly exercises (Ringe, 2010). Hence, one can assume that NPs with high institutional strength in the context of EU politics are also more involved in Brexit affairs.

Yet, in the case of Brexit we observe varying involvement of two very strong NPs. As I will show in the empirical section of this article, the German Bundestag is more intensively involved in the current Brexit negotiations, especially on an informal level, compared to the Austrian Nationalrat. At the same time, however, both parliaments are considered particularly strong in affairs (Auel, Rozenberg, \& Tacea, 2015a; Winzen, 2012).

Relying on the most recent ranking by Auel, Rozenberg and Tacea (2015a, p. 293), the average institutional strength lies at about 0.7 for the German Bundestag and above 0.5 for the Austrian Nationalrat. These scores take into account information rights, capacity of parliaments to process information as well as oversight instruments. The ranking is consistent with similar quantitative rankings (Winzen, 2012) as well as qualitative studies, which ascribe strong institutional prerequisites to the Austrian and German parliaments (Pollak \& Slominski, 2003). In fact, the Austrian Nationalrat is considered by scholarly literature as "exceptionally strong" (Pollak \& Slominski, 2003, p. 723) and placed "in the same league as Germany" (p. 724).

Further to institutional strength, one might expect a stronger involvement of the German Bundestag compared to the Austrian Nationalrat given the sheer size of Parliament and political weight of the country. The absolute size of 709 compared to 183 parliamentarians in the Bundestag and Nationalrat respectively would accordingly translate into a higher level of activity by the German vis-à-vis the Austrian NP. Auel et al. (2015a, p. 78-79), however, show a positive correlation between institutional strength - rather than size of a parliamentand the level of parliamentary activity. Indeed, the parliaments' average activity scores on EU affairs are much alike: 0.34 for the German Bundestag and the Austrian Nationalrat is at 0.22 . Hence, institutional strength and the parliaments' size lend little explanatory power to why the German Bundestag is more involved in Brexit than the Austrian Nationalrat.

What alternative explanations can we turn to in order to account for NPs' activities in the Brexit negotiations? In what follows, I link literature on NPs in EU affairs (e.g., Auel, Rozenberg, \& Tacea, 2015b) to theorization of saliency (e.g., Rauh, 2018). More specifically, I develop an argument according to which vulnerability of a country to the UK's withdrawal from the EU results in an intensive parliamentary involvement via saliency. I contrast this argument to alternative expectations based on party politics, including the role of Euroscepticism (e.g., Auel \& Höing, 2015).

\section{Explaining NPs' Involvement in Brexit}

Institutional strength can arguably not explain NPs' varying involvement in the Brexit negotiations (see Section 2). Alternative explanations in the literature revolve around actors' "willingness to invest political resources to influence political outcomes" (Beyers, Dür, \& Wonka, 2018, p. 6). Scholarship puts forward two reasons for why parliamentarians might be willing to invest resources in an EU issue: the degree of Euroscepticism and party 
politics (e.g., Auel \& Höing, 2015) as well as politicization or saliency of a political event (e.g., Auel \& Christiansen, 2015).

One strand in the literature on NPs in EU affairs theorizes the role of party politics through parliamentgovernment relations. More specifically, scholars analyze the composition of government (Holzhacker, 2002) and the share of Eurosceptic political groups in parliament (Auel \& Höing, 2015). With a view to the composition of government, Saalfeld (2005, p. 357) suggests more intensive parliamentary activities in cases of minority or coalition governments compared to singleparty majority governments. In the cases of the Austrian Nationalrat and the German Bundestag, however, we are concerned with coalition governments only: grand coalitions in Germany as well as in Austria prior to the 2017 elections followed by a coalition in Austria composed of the conservative (Austrian People's Party [ÖVP]) and farright (Freedom Party of Austria [FPÖ]) political groups after the latest elections (until May 21, 2019). According to the argument made by Saalfeld (2005) on the composition of government, we should find no major difference between the Austrian Nationalrat's and German Bundestag's activities on Brexit.

With a view to the role of Euroscepticism, Auel and Höing (2015, p. 381) argue that strong Euroscepticism in public opinion provides incentives for MPs to control their national governments on EU affairs to a greater extent than when Euroscepticism is weak. According to this reasoning, NPs' involvement should be higher when there is a larger share of Eurosceptic parties in parliament. Their presence increases electoral incentives and therefore willingness by MPs to scrutinize EU affairs of both the Eurosceptic party itself and also other parties since they do not want to risk electoral costs (Winzen, 2012, p. 2). Thus, a large share of Eurosceptic parties in parliament should lead to greater NPs' involvement in the negotiations of Brexit:

H1. Euroscepticism expectation: A large share of Eurosceptic party groups in parliament leads to a more involved NP in Brexit affairs.

Next to Euroscepticism, the role of politicization and saliency of EU issues has recently taken center stage in scholarly debate on parliamentary activities (Auel \& Christiansen, 2015; Coremans \& Meissner, 2018; Meissner \& McKenzie, 2019). Next to polarization of opinions and mobilization of a broad set of actors, salience constitutes a major component of high levels of politicization (Rauh, 2018). Saliency influences actors' "willingness to invest political resources" (Beyers et al., 2018 , p. 6). Hence, the expectation that saliency influences NPs' scrutiny activities resonates with research identifying 'willingness' or incentives as crucial for parliamentarians (Winzen, 2013). Saliency, in general, describes the importance, which actors attribute to a specific issue (Beyers et al., 2018, p. 1), or "the extent to which people [such as MPs] care about political issues" (Hartlapp, Metz, \& Rauh, 2014, p. 27). A salient political event therefore can be understood as an opportunity for parliamentarians to invest political resources, whereas MPs are less likely to invest the same amount of resources where an issue has little saliency.

One way of conceptualizing saliency is reasoning backwards from the visibility of an issue in public or in the media. Thus, MPs invest political resources under the premise of making these actions publicly visible. They calculate which issues will resonate with the public knowing that this resonance will increase their own visibility (Auel \& Christiansen, 2015). This is based on the assumption that MPs need to be responsive to citizens (Raunio, 2011). Hence, they calculate electoral costs of their activities, or likewise electoral incentives when investing in a particular issue (Auel \& Christiansen, 2015). Based on these calculations, NPs decide whether to invest political resources into a particular issue.

Saliency of an issue can also occur when large domestic groups in a state will be affected by this particular issue (Auel \& Christiansen, 2015, p. 270). In this context, willingness of MPs to invest resources results from a calculation of actual, material costs (Auel \& Höing, 2015, p. 380). They estimate the possible effects of an EU issue on their domestic constituencies. Based on a calculation of these costs, parliamentarians or NPs follow and act according to particular regional or a national interest in order to remedy or ease the estimated effects (Closa \& Maatsch, 2014, p. 827). Applying this to the context of Brexit, NPs and their parliamentarians are likely to engage more in parliamentary activities if their countries are or will be affected by the UK's exist from the EU. Hence, greater vulnerability to Brexit increases the issue's saliency and thus results in more intense parliamentary involvement in these negotiations:

H2. Saliency expectation: Higher salience of Brexit in an EU member state leads to a more involved NP in these negotiations.

\section{Assessing NPs' Formal and Informal Involvement in EU Affairs}

This article conceives of NPs' involvement in EU affairs as a continuum from low to high contingent on the use of formal and informal parliamentary instruments. The majority of research on NPs in EU affairs focuses on their formal measures such as binding opinions, meetings in EU-committees or plenary debates (Auel et al., 2015b; Miklin, 2015; Pollak \& Slominski, 2009; Rauh, 2015). Little knowledge exists on informal instruments such as meetings on EU issues in specialized committees or direct contacts to the European Commission (hereafter, Commission; with exceptions, Raunio, 2005; Rozenberg, 2017).

This article seeks to address this gap of fully understanding NPs' involvement by covering both formal 
and informal activities ${ }^{1}$ to (a) get access to documents, (b) meet executive actors, and (c) attempt to influence the executive. Hence, I understand NPs' involvement in the Brexit negotiations as a combination of the employment of scrutiny tools as well as their attempted influence on executive positions (Table 1).

Major prerequisites for NPs to hold the executive accountable and to engage in EU affairs are (a) access to documents and (b) consultation of executive bodies in the form of meetings, hearings or debates. While access to documents is vital for legislative actors to scrutinize the executive (Abazi \& Adriaensen, 2017, p. 76), consultation with executive actors is also crucial in order to oversee and influence decision-making. In the context of international negotiations, this implies that NPs have access to relevant negotiation documents either by the Commission as the EU's executive directly or by their national governments; and that they hold meetings, hearings or debates with executive actors. These parliamentary activities are necessary preconditions for, but do not automatically lead to (c) substantive influence on positions of executive actors. Hence, I grasp NPs' involvement as an ordinal scale increasing from the employment of parliamentary activities to attempts to reap influence on governmental positions in the negotiations.

\section{Methods, Operationalization and Data Sources}

In order to trace NPs' involvement in the Brexit negotiations, the article's research design follows a pairwise controlled comparison (Gerring, 2007) of two NPs. More specifically, I select the Austrian Nationalrat and German Bundestag from the universe of all NPs in EU member states, and I thereby select cases of similar institutional strength (see Section 2) in order to analyse the impact of Brexit's saliency (Gerring, 2007). In order to test the influence of Euroscepticism, I combine this pairwise comparison with a within-case comparison over time. In particular, I assess whether an expanded share of Eurosceptic parties in the Austrian Nationalrat and the German Bundestag with the Alternative for Germany (AfD) and FPÖ respectively increases the involvement of these NPs in the Brexit negotiations before and after the elections in 2017.

While I hold the institutional strength of NPs in Austria and Germany constant (see Section 2), Brexit's saliency in these countries varies. In order to measure the degree of saliency, I use vulnerability of these states to the UK's withdrawal from the EU. According to a recent study by Wen et al. (2018), Germany, at a score of 5.48 , will be highly exposed to Brexit and will be affected

Table 1. NPs' involvement in Brexit affairs.

\begin{tabular}{|c|c|c|c|}
\hline \multicolumn{3}{|c|}{ NP's Involvement in Brexit Affairs } & \multirow{2}{*}{$\begin{array}{l}\text { Empirical Examples } \\
\text { Reports by government } \\
\text { Documents circulated in Council } \\
\text { Self-assessed satisfaction with flow and quality of } \\
\text { information }\end{array}$} \\
\hline Low & $\begin{array}{c}\text { (a) } \\
\text { Access to } \\
\text { documents by }\end{array}$ & $\begin{array}{l}\text { Access to negotiation documents } \\
\text { by national governments }\end{array}$ & \\
\hline $\begin{array}{l}1 \\
1 \\
1\end{array}$ & executive actors & $\begin{array}{l}\text { Access to negotiation documents } \\
\text { by the Commission }\end{array}$ & $\begin{array}{l}\text { Commission documents } \\
\text { Documents by negotiation partner }\end{array}$ \\
\hline $\begin{array}{l}1 \\
1 \\
1 \\
1 \\
1\end{array}$ & \multirow{4}{*}{$\begin{array}{l}\text { (b) } \\
\text { Meetings with } \\
\text { executive actors }\end{array}$} & $\begin{array}{l}\text { With national governments } \\
\text { in EU-committees }\end{array}$ & $\begin{array}{l}\text { Discussion on Brexit in EU-committee with members of } \\
\text { national government } \\
\text { Hearings with national delegate in Article } 50 \text { Council } \\
\text { configuration }\end{array}$ \\
\hline 1 & & $\begin{array}{l}\text { With national governments in } \\
\text { specialized committees }\end{array}$ & $\begin{array}{l}\text { Discussion on Brexit in committee on 'Economics and } \\
\text { Energy' }\end{array}$ \\
\hline $\begin{array}{l}1 \\
1\end{array}$ & & $\begin{array}{l}\text { Attendance at political dialogue } \\
\text { with Commission }\end{array}$ & N/A \\
\hline $\boldsymbol{v}$ & & $\begin{array}{l}\text { Informal direct contacts to } \\
\text { Commission's negotiation team }\end{array}$ & $\begin{array}{l}\text { Meetings of party groups with Barnier } \\
\text { Meetings of party groups with Juncker's legal advisor }\end{array}$ \\
\hline & \multirow{2}{*}{$\begin{array}{c}\text { (c) } \\
\text { Influence of } \\
\text { executive actors }\end{array}$} & On governmental position & Communicate position on party level \\
\hline High & & On Commission's position & $\begin{array}{l}\text { Communicate party group's position in bilateral } \\
\text { meeting }\end{array}$ \\
\hline
\end{tabular}

\footnotetext{
${ }^{1}$ Formal rules are written down and can be enforced by a dispute settlement mechanism, while informal rules are usually not written down and cannot be enforced a third dispute settlement mechanism (Stacey \& Rittberger, 2003). Hence, I conceive of a formal parliamentary activity as an instrument which is laid down in formal rules such as reporting duties by the national government to the EU-committee. An informal parliamentary activity, by contrast, refers to measures not foreseen by formal rules such as bilateral contacts between a political group and the Commission's negotiation team.
} 
in terms of exports, services, and the financial sector. Austria, by contrast, will be much less affected according to the same study reaching a score at the lower end of 0.77. This is consistent with other Brexit impact studies such as the ones by KPMG (2017) or the Standard\&Poor Brexit impact index (Gill \& Sakhuja, 2016). According to the latter, Germany is at a relatively high score of 0.8 , while Austria is at 0.3. Based on these data and the conceptualization of saliency as vulnerability to the UK's withdrawal from the EU, I assess Brexit's saliency to be high in Germany and low in Austria.

In order to trace NPs' involvement in the Brexit negotiations, I triangulate data from official parliamentary documents and semi-structured interviews with 18 staff members and MPs from the Austrian Nationalrat, German Bundestag, and the EP in Vienna, Berlin, and Brussels. A first data source is official parliamentary documents in the form of agendas from both parliaments. I systematically mapped the agendas of two committees between 2016 and 2018: Regarding the German Bundestag, these agendas came from the EUcommittee and the specialized committee on 'Economics and Energy'; regarding the Austrian Nationalrat, the agendas from the EU-committee and the main committee were analysed and mapped. Second, semi-structured interviews with 18 staff members and MPs of the German Bundestag, the Austrian Nationalrat, the EP, and NPs' representatives to the EP were carried out in 2018. These officials include, in Germany, current staff members of the parliament's administration, namely the EU-committee and the specialized committee on 'Economics and Energy', of MPs from all political groups except for the AfD, as well as EU and trade specialists of parliamentary groups (Alliance 90/The Greens [Bündnis 90/Die Grünen], The Left [Die Linke], Social Democratic Party of Germany [SPD], Christian Democratic Union of Germany/Christian Social Union in Bavaria [CDU/CSU]). In Austria, they cover EU and trade specialists of the political groups, MPs as well as staff members of MPs from the conservative (ÖVP), social-democratic (Social Democratic Party of Austria), liberal (The New Austria and Liberal Forum [NEOS]) political groups as well as the Greens (which dropped out of the Nationalrat in 2017), but not the FPÖ. Unfortunately, MPs and staff members from the AfD and FPÖ were not available for interviews, partly because the AfD at the time of conducting interviews had no specialists on EU or trade affairs yet. However, I triangulated interview material with information from the committee agendas (see above). Further to that, I included the following questions in my interview questionnaires to which interviewees across political groups and institutional affiliation responded consistently (see Section 8):

Did the AfD's entry into parliament in Germany change the committee's activities with regard to Brexit? If yes, how?
Did the growth of votes in favour of the FPÖ and their gain in parliamentary seats change the committee's activities with regard to Brexit? If yes, how?

In Brussels, staff members and a MEP of Austrian and German nationality were interviewed from political groups including the social democrats (Socialists \& Democrats [S\&D]) and the conservatives (European People's Party [EPP]) further to NPs' representatives from Austria and Germany. For reasons of confidentiality, four interviewees did not want to be cited which is why I refer to these as 'background talks' without identifying their affiliations.

\section{The German Bundestag in the Brexit Negotiations}

In the German Bundestag, the EU-committee is the lead committee in charge of scrutinizing Brexit. Most activities happen on the basis of the EU-committee and are followed by EU specialists in the political groups. The conservative group, CDU/CSU, has an internal 'taskforce Brexit' (background talk), while other parliamentary groups devote one specialist to following the negotiations next to other EU issues. Furthermore, members of the committee on 'Economics and Energy' discuss Brexit on an ad hoc basis.

\subsection{Access to Negotiation Documents}

All MPs, their staff members, and parliamentary group specialists allocated to the lead committee, the EUcommittee, get full access to nearly all Brexit negotiation documents via the parliamentary database EuDox (background talk). Access to documents is wide-ranging and covers documents circulated in the Council, reports by the government, so called 'Drahtberichte' from government about Council meetings, all Commission documents as well as documents on Brexit circulated among executive actors (background talk). All interviewees reported a smooth transition of documents and information from government to parliament without major controversies (Interview 3, 10, 11). Except for negative reports by two interviewees (Interview 4, 12), all documents seem to be made accessible in a timely manner to the full satisfaction of all political groups. This is due to the fact that access is granted also to those documents only available in the reading room.

\subsection{Meetings with Executive Actors}

Even though the EU-committee in the German Bundestag could not commence its activities over the summer 2017 and in the aftermath of elections (September 2017; Interview 10, 11), it developed a dense agenda of meetings with executive actors from government and the Commission. Between 2016 and 2018, Brexit was on the agenda of the EU-committee 28 times and four times on the agenda of the committee 
on 'Economics and Energy' (Figure 1). Next to discussions in the committee, MPs organized public consultations with academics and experts, met with external actors like the Irish foreign ministry or a delegation of the British parliament next to numerous meetings with members of the national government and the EU's negotiation team. Moreover, the negotiation team of the Commission, once Barnier and once Weyand, reported to the German Bundestag.

A refined network of informal contacts to executive actors on a national and EU level complements these official meetings. This includes meetings organized by the EU-committee but not reported in the official agenda (background talk) as well as informal contacts by the political groups. In the context of the EU-committee, interviewees reported further meetings with a representative from the ECJ, the British foreign minister (background talk) in addition to several meetings (not just one) with Barnier (Interview 10, 11).

Informal contacts of the different parliamentary groups within the German Bundestag to executive actors seem to be most extensive in cases of those groups that are in government, namely the conservatives (CDU/CSU) and social democrats (SPD). The 'taskforce Brexit' of the CDU/CSU has a whole range of informal meetings, lunches, and personal contacts to staff members of the national government, state secretaries, and contacts in the federal foreign ministry. Additionally, the taskforce has meetings with staff of the Commission, the negotiation team, including Barnier, and Juncker's legal advisor. The parliamentary group even talks frequently to the EU's counterpart, namely the UK's negotiation team and British state secretaries (background talk). The social democratic political group maintains meetings with executive actors, too. These also include contacts to the UK such as the British foreign ministry on which occasion the political group receives high quality information (Interview 2). Informal contacts appear to be less intensive for groups in opposition. Nevertheless, they do exist. An interviewee working for the liberal FDP reported meetings with the British deputy ambassador, with Katainen, and a planned meeting between the parliamentary group and the deputy of Barnier. The political groups also organize visits to the negotiation partner as liberal MPs did to meet members of the British parliament and government (Interview 9). The Green party group reported talks to the Commission as well as Tusk (Interview 12). Hence, the German Bundestag's contacts to executive actors in the national government, the Commission, as well as even the UK's government can be described as highly intensive.

\subsection{Influence of Executive Actors}

Many of these meetings serve to gather more information about the negotiations as was also affirmed by EP administrators in charge of coordinating with NPs in Brexit (Interview 1-BxI). One reason for this is that the political groups in the German Bundestag have a rather homogeneous position on Brexit. The political groups agree on the Commission's and the government's red lines in the negotiations (Interview 2, 5, 9, 12). Nevertheless, at some of these meetings MPs or their staff members try to shape the government's or Commission's positions

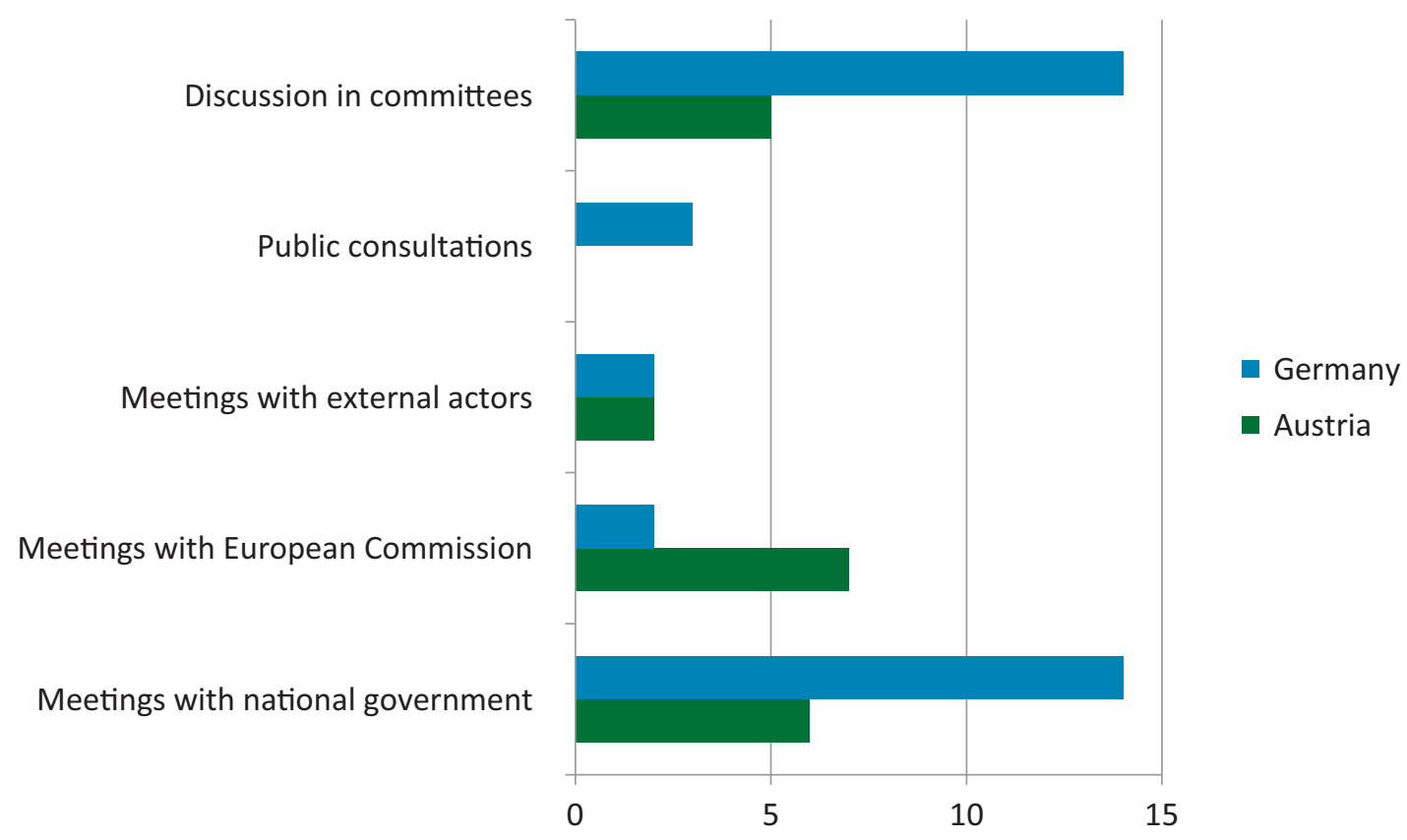

Figure 1. Activities of the Austrian Nationalrat and German Bundestag in the Brexit negotiations. Source: Own compilation based on the agenda of the Bundestag's EU-committee, 2016-2018, information provided by an Austrian MP; and information retrieved from the Austrian Parliament website ('Parlamentskorrespondenz'), 2016-2018, https://www.parlament.gv.at/PAKT/PR/. 
in the negotiations in line with their preferences. In a background talk, an interviewee reported how bilateral meetings with representatives from the Commission or the negotiation team serve to communicate the political group's position (background talk). Influence on executive actors' positions can therefore be described as informal. One of these positions communicated on a bilateral basis was that the withdrawal agreement with the UK needs a timewise clearly restricted transition period and that it must not include budgetary implications (background talk). Both items would require ratification by the German Bundestag.

\section{The Austrian Nationalrat in the Brexit Negotiations}

Similar to Germany, the EU-committee is the lead committee regarding the Brexit negotiations in the Austrian Nationalrat. Scrutiny activities and meetings with governmental actors happen on the basis of the EU-committee (EU-Unterausschuss). Occasionally and where appropriate, Brexit is subject also in specialized committees regarding policies affected by the UK's withdrawal from the EU. As in the German Bundestag, EU specialists in the political groups follow the Brexit negotiations. However, there is no equally fully-fledged structure as in Germany where one specialist or an entire taskforce was devoted specifically to Brexit. Parliamentarians in Austria considered establishing a special procedure in order to scrutinize Brexit (Interview 18, 19, 20). Especially the liberal party group NEOS demanded a permanent hearing of experts on the consequences of Brexit for Austria (Austrian Parliament, 2018). Neither of these two suggestions gathered the necessary majority in parliament and hence remained without success.

\subsection{Access to Negotiation Documents}

In the Austrian Nationalrat, all MPs get full access to all Brexit negotiation documents and reports by the government via a parliamentary EU-database (Interview 18, 19, 20). The level of access is wide-ranging and covers all documents related to $\mathrm{EU}$ issues that are transmitted to government, including all negotiation documents and Council documents (Interview 18, 19, 20). The degree to which parliamentarians are satisfied with the transmission of information from government to the Nationalrat, however, is mixed. On the one hand, interviewees confirm that the Nationalrat is being continuously informed by the government without any interruptions or problems (Interview 15, 21). On the other hand, government is described as not being cooperative. According to an interviewee from an opposition party, it lacks interest in collaborating with the Nationalrat (Interview 22). One interviewee, for instance, described the massive inflow of information as problematic in the sense that the government makes no effort to edit it before transmission (Interview 21).

\subsection{Meetings with Executive Actors}

The lack of interest by government in collaborating with the Nationalrat is also reflected in interaction between MPs and representatives from the national executive in the context of Brexit. Both on a formal and an informal level interaction between the Nationalrat and the government is more limited compared to the German Bundestag (Figure 1). Since 2016, Brexit has been discussed in the EU-committee five times in addition to three plenary debates compared to 14 committee-based debates in the Bundestag. Meetings with representatives from the national government in the EU-committee related to Brexit happened more than twice as much in the Bundestag (14 times) compared to the Nationalrat (6 times). These hearings or meetings were organized with chancellor Kurz, the finance minister as well as the Austrian delegate Schusterschitz in the Brexit-related Article 50 Council configuration. Next to these meetings with the government, MPs also met external actors such as the Irish European ministry.

It is interesting to note that the quantity of formal meetings between the Nationalrat and executive actors from the Commission is apparently higher than in Germany (Figure 1), whereas informal contacts in the Austrian case seem to be more limited compared to Germany. The informal agenda of meetings between party groups in the German Bundestag and Commission representatives does not face a similarly established agenda of meetings in the case of Austria. While in Germany exchange between the conservative party group in government (CDU/CSU) and the Commission was most intensive this does not match interaction between its counterpart in Austria (ÖVP) and the Commission. Rather, an interviewee from this political group reported no informal contacts with executive actors from the EU level (Interview 15). Interviewees from opposition parties, in contrast, do report contacts to the Commission in form of briefings on the level of staff members or with Barnier organized by the Commission's representation in Vienna (Interview 21), in addition to personal contacts between MPs and Commissioners (Interview 22). Nevertheless, the amount and intensity of informal exchange between Austrian parliamentary groups and the Commission does not seem to match the German case.

\subsection{Influence of Executive Actors}

On a substantive level, the Austrian Nationalrat, and its political groups, has developed no genuine position on Brexit. Interviewees reported that they 'took note' (Interview 15) of Brexit, and that the Nationalrat did not work its way into Brexit affairs given the trust into the Commission's position (Interview 21). There was no occasion reported where parliamentarians tried to shape the executives' positions in their favour. 
Comparing the Austrian Nationalrat's involvement in the Brexit negotiations to Germany (Table 2), in both cases the political groups do not yield their full potential of parliamentary rights: Parliamentarians in the Bundestag and in the Nationalrat do not use reasoned opinions or decisions in the EU-committee to bind the government to a certain decision (Interview 18, 19, 20). This is although the right "to bind the government in negotiations at the EU level" is "parliament's 'main weapon"' (Miklin, 2015, p. 403) in Austria and Germany. Nevertheless, both parliaments obtain full access to all negotiation documents and get regular debriefings by government next to meetings with the Commission on a committee-level. On the level of political groups, however, the German Bundestag seems to have a more institutionalized informal procedure to scrutinize Brexit in form of meetings with government and Commission representatives compared to the Austrian Nationalrat. Furthermore, the German Bundestag self-assessed informal influence on some negotiation positions, while this was not reported by interviewees from the Austrian Nationalrat. Hence, both parliaments can be considered to be involved in the Brexit negotiations, but the Bundestag to a larger extent than the Nationalrat.

\section{What Role for Euroscepticism and Saliency in Explaining Parliamentary Involvement in the Brexit Negotiations?}

What factors help understand the rather strong role of the German Bundestag in the Brexit negotiations? How can this be explained vis-à-vis the more limited involvement of the Austrian Nationalrat against the background of similar institutional strength?

\subsection{What Role for Euroscepticism?}

The expectation that the entry into parliament of the Eurosceptic AfD has increased the involvement of the German Bundestag in the Brexit negotiations does not seem to hold. First, the EU-committee was more active before than after the elections in September 2017. Before the elections, in 2017, the committee had a special procedure in order to scrutinize the Brexit negotiations intensively (Interview 10,11). According to this procedure, the EU-committee organized meetings on every occasion of bargaining rounds. This special procedure was not put in place any more after parliamentary elections. Second, none of the interviewees reported substantive influence on the activities of committees or political groups on Brexit due to the AfD's entry into parliament. While some interviewees observe a biting tone in committee meetings (e.g., Interview 3, 7), other staff members recognize no change at all (e.g., Interview 2). Hence, the new share of parliamentary seats of the Eurosceptic AfD appears to have had no significant influence on the German Bundestag's involvement in the Brexit negotiations.

This observation is consistent with the case of the Austrian Nationalrat. Following the elections in 2017, the Eurosceptic FPÖ increased its votes to overall 26 per cent (Bundesministerium für Inneres, 2017) and was until recently (May 21, 2019) in government with the conservative ÖVP. Nevertheless, interviewees consistently reported no influence of this change on the activities of the EU-committee whatsoever (Interview 18, 19, 20, $21,22,24)$. The FPÖ is described as relying heavily on the position of its coalition partner regarding Brexit affairs with no genuine FPÖ-position (Interview 21). Brexitaffairs continue to be 'business as usual' (Interview 18,

Table 2. Involvement of the German Bundestag and Austrian Nationalrat in the Brexit negotiations.

\begin{tabular}{|c|c|c|c|c|}
\hline \multicolumn{3}{|c|}{ Involvement } & \multirow{2}{*}{$\begin{array}{l}\text { German Bundestag } \\
\text { Extensive range } \\
\text { of documents }\end{array}$} & \multirow{2}{*}{$\begin{array}{l}\text { Austrian Nationalrat } \\
\text { Extensive range } \\
\text { of documents }\end{array}$} \\
\hline Low & $\begin{array}{c}(\mathrm{a}) \\
\text { Access to }\end{array}$ & $\begin{array}{l}\text { Access to negotiation documents } \\
\text { by national governments }\end{array}$ & & \\
\hline I & $\begin{array}{l}\text { documents by } \\
\text { executive actors }\end{array}$ & $\begin{array}{l}\text { Access to negotiation documents } \\
\text { by the Commission }\end{array}$ & $\begin{array}{l}\text { All negotiation } \\
\text { documents }\end{array}$ & $\begin{array}{l}\text { All negotiation } \\
\text { documents }\end{array}$ \\
\hline 1 & \multirow{4}{*}{$\begin{array}{l}\text { (b) } \\
\text { Meetings with } \\
\text { executive actors }\end{array}$} & $\begin{array}{l}\text { With national governments } \\
\text { in EU-committees }\end{array}$ & 14 meetings & 6 meetings \\
\hline 1 & & $\begin{array}{l}\text { With national governments } \\
\text { in specialized committees }\end{array}$ & On ad-hoc basis & On ad-hoc basis \\
\hline I & & $\begin{array}{l}\text { Attendance at political dialogue } \\
\text { with Commission }\end{array}$ & - & - \\
\hline $\begin{array}{l}1 \\
1\end{array}$ & & $\begin{array}{l}\text { Informal direct contacts to } \\
\text { Commission's negotiation team }\end{array}$ & $\begin{array}{l}\text { Intensive informal } \\
\text { contacts }\end{array}$ & $\begin{array}{l}7 \text { official meetings, } \\
\text { informal contacts }\end{array}$ \\
\hline$\downarrow$ & (c) & On governmental position & Limited and informal & No influence attempted \\
\hline High & $\begin{array}{c}\text { Influence of } \\
\text { executive actors }\end{array}$ & On Commission's position & Limited and informal & No influence attempted \\
\hline
\end{tabular}


19, 20). Hence, there is no evidence that the increased share of Eurosceptic parties led to more involved parliaments in Austria or Germany.

\subsection{Vulnerability to Brexit and Its Saliency}

In line with the saliency expectation, interviewees reported a higher degree of importance ascribed to gathering documents and being briefed in the case of the German Bundestag compared to the Austrian Nationalrat (Interview 1-BxI, 3, 6-BxI). While all NPs were assigned interest in up to date information (Interview 1-BxI), the importance attached to his was higher in Germany than in Austria: German interviewees, for example, stated that the Bundestag has a "strong need for information" (Interview 14) and that parliamentarians regard direct and immediate information as crucial (Interview 3). Therefore, the Bundestag's office in Brussels regularly includes news on Brexit from the EU institutions in its reports to Berlin (Interview 5-Bxl). This is remarkably different in Austria where interviewees "took notice" (Interview 15) of Brexit, and where parliamentarians are relieved not to be part of the negotiations (Interview 24). Rather, activities or debates in the Austrian Nationalrat revolve around the long-term, generic consequences of Brexit such as on the budget rather than the negotiations on the withdrawal agreement as such (Interview 22).

Other than in EU international negotiations with Canada on CETA, the reason for attention to Brexit affairs in the German Bundestag does not lie in ideological polarization among parliamentarians. Interviewees consistently reported support for the executive, especially for the Commission's chief negotiator Barnier (Interview 2, 3, 9). Even the leftist party group's position on Brexit is to some extent congruent with the one of the conservatives (Interview 10, 11). In the Austrian Nationalrat, Brexit is also not ideologically contested (Interview 7-8-BxI). Activities on Brexit in the German Bundestag do also not result from public visibility (Interview $4,5,15$ ). In other words, the mechanism through which Brexit receives attention in the German Bundestag (and remained absent in the Austrian Nationalrat) does not stem from ideological contestation or visibility of the topic in the press.

Rather, the difference between Austria and Germany is their levels of exposure to the UK's withdrawal and the resulting regional and national interests which the German Bundestag represents in the negotiations: MPs and MEPs were described as 'lobbying' Michel Barnier in favour of regional interests stemming from their constituencies (Interview 2, 9, 6-BxI). Hence, Brexit resonates with individuals, civil society organizations or business groups in local constituencies (Interview 12). One interviewee explained its political group's interest in smooth trade relations between the UK and its region Baden-Wuerttemberg which results in parliamentary activities on the Irish border issue (Interview 9). Another interviewee made the example of fisheries in the region
Niedersachsen which resonates with its MEP's local constituency (Interview 6-BxI). Domestic groups approach parliamentarians on specific issues. This is why MPs seek constant information to understand the current state of play of the Brexit negotiations. Next to regional interests, a genuine German interest seems also to have emerged over the course of the Brexit negotiations. These national interests reach out to export, engineering and particularly the automobile industry (Interview 6-Bxl). The automobile company BMW appears to be a crucial component of German interests in the Brexit negotiations as it was mentioned several times, and the Bundestag devotes time to individual meetings with BMW representatives (background talk). An interviewee affirmed that the Brexit talks are also about pushing national interests through (Interview 6-BxI).

In Austria, in contrast to Germany, Brexit is neither visible in public nor salient with individuals or civil society organizations. Likewise, the country developed no genuine Austrian interest in the context of the Brexit negotiations (Interview 21). Rather, Austria abstains from being involved in the Article 50 talks and puts forward no specific interests (Interview 21). As elaborated by an interviewee this is also because there is little interdependence between Austria and the UK so that Brexit gains little attention in parliament (Interview 21). The low relevance to domestic groups and the absence of specific national interests result in an almost complete retraction of Austria in the Brexit negotiations. This finding resonates with research on the Austrian parliament which ascribes to it exceptional institutional strength which is not being actively used to scrutinize EU affairs (Pollak \& Slominski, 2003, p. 723).

\section{Conclusion}

The Austrian Nationalrat and the German Bundestag are considered exceptionally strong NPs in scrutinizing EU affairs. Both parliaments used their legislative instruments to great extent in negotiations of EU trade agreements such as the one with Canada on CETA. Yet, as this article shows, their involvement varies in the current Brexit negotiations. While the German Bundestag uses formal and informal contacts to executives, including the national government, the Commission, as well as representatives from the UK, the Austrian Nationalrat is less active in the Article 50 negotiations, especially so on an informal level.

In order to explain this puzzle, I argued that the countries' varying vulnerability to the UK's withdrawal from the EU explains the different levels of engagement in the Brexit negotiations. Germany is expected to be more strongly affected by Brexit than Austria, which is why the Article 50 negotiations gain more attention in the Bundestag compared to the Nationalrat. German MPs ascribed importance to scrutinizing Brexit affairs because they calculated material costs for the country and its regions stemming from the UK's withdrawal. Their activities were therefore directed towards gathering informa- 
tion on the Brexit negotiations and transmitting this to affected domestic constituencies.

The results of this study are particularly relevant for two strands in the literature on parliaments in EU affairs. Firstly, the article speaks to theorization of saliency and its impact on parliamentary behavior. One way of conceptualizing saliency is through public visibility of a political issue or event (Rittberger \& Schimmelfennig, 2006). Saliency can also be explored through the extent to which a country will be domestically affected by an event or an EU decision. Putting it another way, MPs may invest political resources because they calculate domestic, material costs arising from a certain issue. Secondly, the article contributes to research on NPs in the negotiation of EU international agreements on which only a handful of studies exists so far (Jančić, 2017; RoedererRynning \& Kallestrup, 2017). Having traced NPs' involvement in Brexit affairs, the results of this article confirm the relevance of saliency for parliaments' activities within the realm of EU international negotiations. Given that the German parliament was actively involved already between 2016 and 2018, we might observe a more engaged Bundestag in continued Article 50 negotiations. Depending on the vote on the current withdrawal agreement in the UK's parliament, we can expect an even more active German Bundestag in the negotiations on future UK-EU relations given that the agreement is most likely going to be mixed (in case there will be no Brexit without a withdrawal agreement).

\section{Acknowledgments}

I gratefully acknowledge comments and suggestions by Carlos Closa and Johannes Pollak, the editors of the thematic issue Christine Neuhold and Guri Rosén as well as two anonymous reviewers. All remaining errors are my own. Open access funding provided by University of Vienna.

\section{Conflict of Interests}

The author declares no conflict of interests.

\section{References}

Abazi, V., \& Adriaensen, J. (2017). Allies in transparency? Parliamentary, judicial and administrative interplays in the EU's international negotiations. Politics and Governance, 5(3), 75-86.

Auel, K., \& Christiansen, T. (2015). After Lisbon: National parliaments in the European Union. West European Politics, 38(2), 261-281.

Auel, K., \& Höing, O. (2015). National parliaments and the Eurozone crisis: Taking ownership in difficult times? West European Politics, 38(2), 375-395.

Auel, K., Rozenberg, O., \& Tacea, A. (2015a). To scrutinise or not to scrutinise? Explaining variation in EUrelated activities in national parliaments. West Euro- pean Politics, 38(2), 282-304.

Auel, K., Rozenberg, O., \& Tacea, A. (2015b). Fighting back? And, if so, how? Measuring parliamentary strength and activity in EU affairs. In C. Hefftler, C. Neuhold, O. Rozenberg, \& J. Smith (Eds.), The Palgrave handbook of national parliaments and the European Union (pp. 60-94). Basingstoke: Palgrave Macmillan.

Austrian Parliament. (2018). Nationalrat startet Aufruf zu humanitärer Hilfe in Afrin (Parlamentskorrespondenz 297) [Parliament's correspondence]. Vienna: Austrian Parliament Building. Retrieved from https://www.parlament.gv.at/PAKT/PR/JAHR_2018/ PK0297

Beyers, J., Dür, A., \& Wonka, A. (2018). The political salience of EU policies. Journal of European Public Policy, 25(11), 1726-1737.

Bundesministerium für Inneres. (2017). Stimmenstärkste Partei pro Bundesland [Strongest party per country]. Bundesministerium für Inneres. Retrieved from https://wahl17.bmi.gv.at

Christiansen, T., \& Fromage, D. (Eds.). (2019). Brexit and democracy: The role of parliaments in the UK and the European Union. Basingstoke: Palgrave Macmillan.

Closa, C. (2019). Inter-institutional cooperation and intergroup unity in the shadow of veto: The construction of the EP's institutional role in the Brexit negotiations. Journal of European Public Policy. Advance online publication. https://doi.org/10.1080/13501763. 2019.1603249

Closa, C., \& Maatsch, A. (2014). In a spirit of solidarity? Justifying the European financial stability facility (EFSF) in national parliamentary debates. Journal of Common Market Studies, 52(4), 826-842.

Cooper, I. (2012). A 'virtual third chamber' for the European Union? National parliaments after the Treaty of Lisbon. West European Politics, 35(3), 441-465.

Coremans, E., \& Meissner, K. L. (2018). Putting power into practice: Administrative and political capacity building in the European Parliament's committee for international trade. Public Administration, 96(3), 561-577.

De Ruiter, R. (2013). Under the radar? National parliaments and the ordinary legislative procedure in the European Union. Journal of European Public Policy, 20(8), 1196-1212.

European Court of Justice. (2017). The free trade agreement with Singapore cannot, in its current form, be concluded by the EU alone (Press Release No 52/17). Luxembourg: Court of Justice of the European Union. Retrieved from https://curia.europa.eu/jcms/ upload/docs/application/pdf/2017-05/ cp170052en.pdf

Gerring, J. (2007). Case study research: Principles and practices. Cambridge: Cambridge University Press.

Gill, F., \& Sakhuja, A. (2016). Who has the most to lose from Brexit? Introducing the Brexit sensitivity index. Standard \& Poor's Global Ratings. Retrieved from 
https://www.capitaliq.com/CIQDotNet/Credit Research/RenderArticle.aspx?articleld=1652746 \&SctArtld=390748\&from=CM\&nsl_code=LIME \&sourceObjectld=9677945\&sourceRevld=1 \&fee_ind=N\&exp_date=20260609-16:18:50

Hartlapp, M., Metz, J., \& Rauh, C. (2014). Which policy for Europe? Power and conflict inside the European Commission. Oxford: Oxford University Press.

Holzhacker, R. (2002). National parliamentary scrutiny over EU issues: Comparing the goals and methods of governing and opposition parties. European Union Politics, 3(4), 459-479.

Jančić, D. (2017). TTIP and legislative? lexecutive relations in EU trade policy. West European Politics, 40(1), 202-221.

KPMG. (2017). Brexit: The view from Europe. London: KPMG. Retrieved from https://assets.kpmg.com/ content/dam/kpmg/uk/pdf/2017/02/brexit-theview-from-europe.pdf

Meissner, K. L., \& McKenzie, L. (2019). The paradox of human rights conditionality in EU trade policy: When strategic interests drive policy outcomes. Journal of European Public Policy, 26(9), 1273-1291. https:// doi.org/10.1080/13501763.2018.1526203

Miklin, E. (2015). The Austrian Parliament and EU affairs: Gradually living up to its legal potential. In C. Hefftler, C. Neuhold, O. Rozenberg, \& J. Smith (Eds.), The Palgrave handbook of national parliaments and the European Union (pp. 389-406). Basingstoke: Palgrave Macmillan.

Pollak, J., \& Slominski, P. (2003). Influencing EU politics? The case of the Austrian parliament. Journal of Common Market Studies, 41(4), 707-729.

Pollak, J., \& Slominski, P. (2009). Zwischen Deund Reparlamentarisierung-Der Österreichische Nationalrat und seine Mitwirkungsrechte in EU-Angelegenheiten [Between de- and reparliamentarization-The Austrian Nationalrat and its scrutiny rights in EU affairs]. Österreichische Zeitschrift für Politikwissenschaft, 38(2), 193-212.

Rauh, C. (2015). Communicating supranational governance? The salience of EU affairs in the German Bundestag, 1991-2013. European Union Politics, 16(1), 116-138.

Rauh, C. (2018). EU politicization and policy initiatives of the European Commission: The case of consumer policy. Journal of European Public Policy, 26(3), 344-365.

Raunio, T. (2005). Holding governments accountable in European affairs: Explaining cross-national variation. The Journal of Legislative Studies, 11(3/4), 319-342.

Raunio, T. (2011). The gatekeepers of European integration? The functions of national parliaments in the EU political system. Journal of European Integration, 33(3), 303-321.

Ringe, N. (2010). Who decides, and how? Preferences, uncertainty, and policy choice in the European Parliament. Oxford: Oxford University Press.

Rittberger, B., \& Schimmelfennig, F. (2006). Explaining the constitutionalization of the European Union. Journal of European Public Policy, 13(8), 1148-1167.

Roederer-Rynning, C., \& Kallestrup, M. (2017). National parliaments and the new contentiousness of trade. Journal of European Integration, 39(7), 811-825.

Rozenberg, O. (2017). The role of national parliaments in the EU after Lisbon: Potentialities and challenges (PE 583.126). Brussels: European Parliament's Policy Department for Citizens' Rights and Constitutional Affairs. Retrieved from http://www. europarl.europa.eu/RegData/etudes/STUD/2017/ 583126/IPOL_STU(2017)583126_EN.pdf

Saalfeld, T. (2005). Deliberate delegation or abdication? Government backbenchers, ministers and European Union legislation. The Journal of Legislative Studies, 11(3/4), 343-371.

Stacey, J., \& Rittberger, B. (2003). Dynamics of formal and informal institutional change in the EU. Journal of European Public Policy, 10(6), 858-883.

Wen, C., Bart, L., Philip, M., Raquel, O. A., Mark, T., \& Frank, O. (2018). The continental divide? Economic exposure to Brexit in regions and countries on both sides of the Channel. Articles in Regional Science, 97(1), 25-54.

Winzen, T. (2012). National parliamentary control of European Union affairs: A cross-national and longitudinal comparison. West European Politics, 35(3), 657-672.

Winzen, T. (2013). European integration and national parliamentary oversight institutions. European Union Politics, 14(2), 297-323.

\section{About the Author}

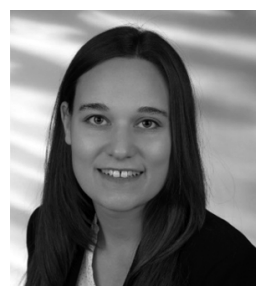

Katharina Luise Meissner is Assistant Professor at the Centre for European Integration Research at the University of Vienna. She holds a PhD in Political and Social Sciences from the European University Institute. Her research focuses on the EU, international trade, and the role of parliaments therein. 


\section{COGITATIO}

\section{Appendix}

\section{List of interviews}

Interview 2 (2018) Staff member, German Bundestag. May 03, 2018. Berlin, Germany. Interview 3 (2018) Staff member, German Bundestag. May 03, 2018. Berlin, Germany. Interview 4 (2018) Staff member, German Bundestag. May 03, 2018. Berlin, Germany. Interview 5 (2018) Staff member, German Bundestag. May 03, 2018. Berlin, Germany. Interview 9 (2018) Staff member, German Bundestag. May 07, 2018. Berlin, Germany. Interview 10 and 11 (2018) Staff members, German Bundestag. May 07, 2018. Berlin, Germany. Interview 12 (2018) Staff member, German Bundestag. May 07, 2018. Berlin, Germany. Interview 14 (2018) Staff member, German Bundestag. May 29, 2018. Vienna, Austria. Interview 15 (2018) MP, Austrian Nationalrat. June 15, 2018. Vienna, Austria. Interview 18, 19 and 20 (2018) Staff members, Austrian Nationalrat. June 21, 2018. Vienna, Austria. Interview 21 (2018) Staff member, Austrian Nationalrat. July 02, 2018. Vienna, Austria. Interview 22 (2018) MP, Austrian Nationalrat. July 12, 2018. Vienna, Austria. Interview 24 (2018) MP, Austrian Nationalrat. September 12, 2018. Vienna, Austria. Interview 1-Bxl (2018) Staff member, EP. October 09, 2018. Brussels, Belgium. Interview 5-Bxl (2018) Staff member, German Bundestag. October 10, 2018. Brussels, Belgium. Interview 6-Bxl (2018) Staff member, EP. October 11, 2018. Brussels, Belgium. 